\title{
Cutaneous Squamous Cell Carcinoma of the Head and Neck pN3 TNM Finding v8
}

National Cancer Institute

\section{Source}

National Cancer Institute. Cutaneous Squamous Cell Carcinoma of the Head and Neck pN3 TNM Finding v8. NCI Thesaurus. Code C133233.

Cutaneous squamous cell carcinoma of the head and neck with metastasis in a lymph node larger than $6 \mathrm{~cm}$ in greatest dimension and ENE(-); or metastasis in a single ipsilateral lymph node larger than $3 \mathrm{~cm}$ in greatest dimension and $\mathrm{ENE}(+)$; or metastases in multiple ipsilateral, contralateral, or bilateral lymph nodes, any with $\mathrm{ENE}(+)$. (from AJCC 8th Ed.) 